\title{
Comparative analysis of technical efficiency of catfish farms using different technologies in Lagos State, Nigeria: a Data Envelopment Analysis (DEA) approach
}

Isaac Busayo Oluwatayo ${ }^{1^{*}}$ and Taiwo Adeola Adedeji ${ }^{2}$

\begin{abstract}
Background: There is no gainsaying the fact that demand for proteins has continuously outweighed supply in Nigeria. This is largely due to the rising population on one part and the low level of technology to cope with changing production practices specifically in the fishery sub-sector and agricultural production in general on the other part. The resultant effect of this is the widening demand and supply gap which often culminate in farmers devising different technologies or approaches to mediate the shortfall. This study therefore examined comparative analysis of technical efficiency among catfish producers using different construction designs in Lagos State, Nigeria. A sample consisting of 43 earthen catfish producers, 33 cage culture and 37 plastics tank was selected from three agricultural zones in the state. Data collected were analysed using descriptive statistics, budgetary and profitability analysis, regression analysis and Data Envelopment Analysis approach.
\end{abstract}

Results and main findings: Overall average technical efficiency estimates obtained under the Variable Returns to Scale (VRS) and Constant Returns to Scale (CRS) specification for earthen catfish producers were 0.92 and 0.73 , respectively. The overall average technical efficiency estimates for VRS and CRS specification under cage culture catfish producers were 0.92 and 0.79 , respectively, and overall mean estimates obtained for VRS and CRS specification under plastic tank catfish producers were 0.95 and 0.69 , respectively. However, for CRS under earthen pond, two variables, sex and age of farmer with $t$ values of -2.10 and 1.82, were equally significant. Again, for CRS under cage culture, two variables were significant, and these were years of formal education and primary occupation with $t$ values of -2.09 and 2.16. Under CRS for plastic tank, two variables_age and religion with $t$ values of 2.04 and 1.99 —were significant at 5 and $10 \%$, respectively.

Conclusions: The study concludes that the most efficient and profitable construction designs among earthen, cage culture and plastic tank are the earthen pond. This is because of its cost-effectiveness in terms of design and management as well as the limited impact on the environment. As indicated, years of formal education were significant in all the designs revealing that education plays a pivotal role in efficiency. The implication of the findings is that famers should be better educated on the dangers inherent in polluting water bodies to avoid contamination (since the earthen pond is the most efficient) to enhance catfish production if the much desired production increase is to be sustained.

Keywords: Catfish production, Construction designs, DEA, Lagos State, Technical efficiency

JEL Classification: D20, L25, Q12, Q16, R32

\footnotetext{
*Correspondence: isaacoluwatayo@yahoo.com

1 Department of Agricultural Economics and Animal Production,

University of Limpopo, Mankweng, South Africa

Full list of author information is available at the end of the article
} 


\section{Introduction}

In Nigeria, there is wide gap between food production and population growth, hence the rising wave of food insecurity. While food production increases at the rate of $2.5 \%$, food demand increases at a rate of more than $3.5 \%$ due to high rate of population growth of $2.83 \%$ [ 8 , 16]. The apparent disparity between the rate of food production and demand for food in Nigeria has led to rising food importation and soaring food prices. The demand and supply gap for animal protein intake is very high. The FAO [17] recommends that the minimum intake of protein by an average person should be $65 \mathrm{~g}$ per day; of this, 36 g (i.e. $40 \%$ ) should come from animal sources. Nigeria is presently unable to meet this requirement. The animal protein consumption in Nigeria is less than $8 \mathrm{~g}$ per person per day, which is a far cry from the FAO minimum recommendation $[17,25]$. As a result of the above, widespread hunger and malnutrition are evident in the country. Animal scientists, economists and policy makers are of the opinion that the development of the livestock industry and most especially the fishery sub-sector is the only option for bridging the generally known protein deficiency gap in Nigerian's diets [23, 31].

Fish farming, also known as aquaculture, involves the planned growth and cultivation of fish harvesting as food, as opposed to catching fish in the wild. It provides lucrative returns to the farmers, employment in rural areas, besides supplying good quality protein diet for the people [27]. The contribution of the fisheries sub-sector to the Gross Domestic Product (GDP) figure which was 1.1\% in 1995 increased to $3.2 \%$ in 2007, and it is expected to reach $5 \%$ in 2020 [12]. In addition to fish protein which is ranked the cheapest among animal protein sources, fish provides high-quality calories, fats and vitamins [29]. Furthermore, fish culture generates income for all categories of people involved in it as well as providing foreign exchange for the nation.

Among the culturable species of food fish in Nigeria are carp, tilapia, catfish, etc. Meanwhile, catfish is the most sought after. It is very popular among fish farmers and commands very good commercial value in the markets. Consequently, the catfish is vital to the sustainability of the aquaculture industry in the country having in possession the following good qualities identified by Osawe [28] as they survive in different culture systems and diverse environments, grow very fast and have high fecundity, improved survival of the fry and adaptation to supplemental feed. These qualities have placed catfish farming in good position to serve as the only way of boosting fish production and thereby move the country towards self-sufficiency in fish supply. To achieve economic optimum output and thus profitability, resources have to be optimally and efficiently utilized. The efficiency of input utilization in any agricultural enterprise enhances the profitability of such enterprise. The ability of catfish producers to adopt new technology and achieve sustainable production depends on their level of technical efficiency. According to Jarzebowski [18], efficiency studies help countries to determine the extent to which they can raise productivity by improving efficiency with the existing resource base and available technology. While a number of studies on efficiency have used the Stochastic Frontier Approach (SFA) that is hinged on the production function (parametric), it is also common in the literature to use the Data Envelopment Analysis (DEA), a deterministic tool of which the analytical basis is an optimization problem [21]. While the former (SFA) could suffer from functional form misspecification, the latter (DEA) is free from misspecification of functional form.

As observed by [3, 24], many African farmers are still using low-yielding agricultural technologies, which lead to low productivity. Also, it is always argued that the relevant question for agricultural policy makers is whether the agricultural sector can be made more efficient, by achieving more output with the current input level, or achieving the current output with less input use than is currently observed. An important step in answering this question is to identify the behaviour of productivity and its components. The concept of efficiency is at the core of economic theory. The theory of production economics is concerned with optimization and this implies efficiency. The crucial role of efficiency in increasing agricultural output has been widely recognized by researchers and policy makers alike. It is no surprise; therefore, that considerable effort has been devoted to the analysis of farm level efficiency in developing countries.

An underlying premise behind much of this work is that if farmers are not making efficient use of the existing technology, their efforts designed to improve efficiency would be more cost-effective than introducing new technologies as a means of increasing agricultural outputs $[6$, $7,26]$.

Generally, fish farming as an industry is faced with some problems which include inadequate supply of fishing inputs (fingerlings and feed), rising cost of trawling operation, insufficient production of fingerlings of cultivable fish species, lack of sufficient least cost-effective feed for fish culture among others. Despite the present fish demand of about 2.66 million metric tonnes and estimated domestic production of about 800,000 metric tonnes in Nigeria, there is still a shortfall of 1.2 million metric tonnes in domestic fish production $[2,15]$. This inability of the fish farming industry to expand fast enough in the supply of the required quantities of fish being demanded for has been linked to low or inadequate intake of protein among the Nigeria households [1, 17]. 
While estimated fish demand showed a steady increase occasioned by increase in population, there is a drastic reduction in the level of animal protein supply and consumption of protein in Nigeria. The better performance in quality and quantity of fish nutrient is responsible for its increase in demand and investment in fishery in Nigeria. However, the higher demand has not been met by the supply of the product because most ground fish pond could not operate due to some technical inefficiency that exists among the fish farmers in the state.

In view of the foregoing, it is therefore important to examine technical efficiency among catfish producers using different construction designs in Lagos state, Nigeria and suggest better ways of enhancing productivity in order to enhance more catfish availability for consumption among the rapidly increasing Nigerian populace. The study tried to address the following research questions:

- What are the socioeconomic characteristics of catfish producers in the Lagos State, Nigeria?

- What are the profitability levels of catfish farmers employing different construction designs in the study area?

- Are there differences in the technical efficiency of catfish producers using different construction designs?

The general aim of this study was to examine and compare technical efficiency of catfish farmers using different construction designs in Lagos State, Nigeria. The specific objectives of the study were to profile socioeconomic characteristics of catfish producers in Lagos State, ascertain the profitability levels of catfish farmers using different construction designs and examine the differences in technical efficiency of catfish farmers using different construction designs in the study area.

Improving the fishery sub-sector through intensive catfish production is a good step in the right direction in terms of conservation of foreign exchange earnings in the country. When this happens, the foreign exchange earning that would have been used for fish importation would be conserved for other uses in the economic development of the nation.

\section{Theoretical and conceptual framework}

Following Lovell [22], the productivity of a production unit can be measured by the ratio of its output to its input. However, productivity changes due to differences in production technology, differences in the efficiency of the production process and differences in the environment in which production takes place. The main interest here is in isolating the efficiency component in order to measure its contribution to productivity. In microeconomics, production theory of firm's input and output combinations is depicted using a production function. Using such a function, one can show the maximum output which can be achieved with any possible combination of inputs, that is, one can construct a production technology frontier [30].

Production is a process, and as such it occurs through time and through space. Because it is a flow concept, production is measured as a "rate of output per period of time." There are three aspects to production processes:

- the quantity of commodity produced,

- the form of good produced,

- the temporal and spatial distribution of the commodity produced.

A production process can be defined as any activity that increases the similarity between the pattern of demand for goods, and the quantity, form and distribution of these goods available to the market place.

In the short run, the output can be increased for a production function by increasing the amount of the variable factor, usually taken to be labour. Thus, the responsive change in the output due to a change in the variable input keeping all other things constant is called Return to a factor. In the long run, output of goods can be increased by increasing all the factors (i.e. both labour and capital). In the long run, all factors are variable, and thus, the responsive change in the output due to proportional change in the size or scale of inputs or factors of production is called Returns to Scale $[10,11,20]$. Increasing Returns to Scale occurs when the \% change in output is $>\%$ change in input. Decreasing Returns to Scale occurs when the $\%$ change in output is $<\%$ change in input and Constant Returns to Scale occurs when the \% change in output $=\%$ change in input.

\section{Different concepts of efficiency}

In the immediate post-war years, there was a general interest in growth, efficiency and productivity. The concept of production efficiency in the use of farm resources is concerned with the relative performance of the processes used in transforming a given set of inputs into largest possible quantity of outputs. Economic theory identifies at least three types of efficiency: technical, allocative and economic efficiencies. Farrell [14] introduced a method to decompose the economic (cost/overall) efficiency of a production unit into its technical and allocative components. The first theories and papers appeared in 1957, with the Solow (macroeconomic approach) and Farrell (microeconomic approach) studies. In particular, Farrell [14] (following the work [19]) involves new insights into two important issues: How to 
define efficiency and productivity and how to calculate the benchmark technology and efficiency measures?

Farrell [14] by drawing inspiration from $[4,5,19]$ divided farm efficiency into three groups, namely technical, allocative (or price) and economic (or overall). Farrell defined technical efficiency (TE) as the firm's ability to produce maximum output given a set of inputs and technology. Stated differently, technical inefficiency reflects the failure of attaining the highest possible level of output given inputs and technology. He conceptualized allocative efficiency (AE) as the measures of the firm's success in choosing the optimal input proportions, given their respective prices and available technology, i.e. where the ratio of marginal products for each pair of inputs is equal to the ratio of their market prices, while he described economic efficiency (EE) as a measure of overall efficiency of a firm and is equal to the product of technical efficiency (TE) and allocative efficiency (AE)

$$
\mathrm{EE}=\mathrm{TE} \times \mathrm{AE}
$$

As proposed by Farrell, the two primary scalar measures of efficiency for the input-oriented problem are as follows:

1. Technical efficiency (TE) which is measured as the ratio between the observed output and the maximum output, under the assumption of fixed input, or, alternatively, as the ratio between the observed input and the minimum input under the assumption of fixed output, i.e. it is just the proportional reduction in inputs possible for a given level of output in order to obtain the efficient input use.

2. Allocative or price efficiency (AE) refers to the ability to combine inputs and outputs in optimal proportions in the light of prevailing prices and is measured in terms of behavioural goal of the production unit like, for example, observed optimum cost or observed optimum profit, i.e. it reflects the ability of the firm to use the inputs in optimal proportions, given their respective prices.

Efficiency is measured by the ratio of output to inputs. Efficiency in a given time period is measured relative to all other time periods with the simple restriction that production of each output in each time period lies on or below the efficient frontier. The efficiency score in the presence of multiple input and output factors is defined by Fare et al. [13] as:

$$
\text { Efficiency }=\frac{\text { Weighted sum of outputs }}{\text { Weighted sum of inputs }}
$$

Efficiency as defined by the pioneering work of Farrell [14] is the ability to produce at a given level of output at the lowest cost. All agencies use a range of inputs, including labour, capital, land, fuel and materials, to produce services. If an agency is not using its inputs in a technically efficient manner, it is possible to increase the quantities of outputs without increasing inputs, or to reduce the inputs being used to produce given quantities of outputs.

In Farrell's approach, the measurement of economic efficiency is linked to the use of a frontier production function, in opposition to the notion of average performance underlying most of the econometric literature on the production function up to the time of Farrell contribution. Farrell's efficiency measures are completely data based, so no specific functional form needs to be predefined.

\section{Research methodology \\ Study area}

The study was conducted in Lagos State, Nigeria. Lagos State is one of the 36 states in Nigeria created in 1967 and geographically located in the low-lying coastal zone of South Western Nigeria. It lies approximately between longitudes $2042^{\prime} \mathrm{E}$ and $3042^{\prime} \mathrm{E}$ and latitudes $6022^{\prime} \mathrm{N}$ and $6052 \mathrm{~N}$ of the equator. The southern boundary of the state is formed by the $180 \mathrm{~km}$ long Atlantic coastline, while its northern and eastern boundaries are shared with Ogun State. The Western boundary is bordered by the Republic of Benin. Lagos State is the smallest state occupying $3577 \mathrm{~km}^{2}$ (about $0.4 \%$ ) of the entire land area of the country. This size, however, is inhabited by about 5.52 million people (about $6.2 \%$ ) of the national population of 120 million (1991 census). Lagos State has 1300 persons $/ \mathrm{km} ; 2.17 \%$ of the 357,700 hectares area of the state is made up of Lagoons and waterways. Many Lagos State residents work in the fishery, farming and livestock industry. Small and large-scale fishery is common in many coastal areas of the state including Badagry, Ibeju Lekki and Epe. The State has five main agricultural zones: Badagry, Epe, Ikorodu, Lekki and Ikeja.

\section{Sampling procedure and sample size}

A multistage sampling technique was employed in the selection of respondents in the study area. In the first stage, purposive sampling technique was used to select three agricultural zones as compiled by the Lagos State Agricultural Development Authority (LSADA) in Badagry, Epe and Ikorodu local government areas (LGAs) of the state. LSADA was formerly called Lagos State Agricultural Development Programme which was established in 1987. The LGAs were selected based on the predominance of fishing activities in these areas. The second stage involved the use of a random sampling technique to select fishing communities from each of the selected 
agricultural zone. The third stage was the random selection of registered fish farmers in each of the selected fishing communities. About 130 questionnaires were administered, but only 113 were correctly completed by the respondents (farmers), and these were the ones used in the analysis. Data collected include information on socioeconomic characteristics such as sex age, primary occupation, years of educational level, household size. Data were also collected on farm inputs and outputsfingerlings, feeds, family labour and hired labour, stocking capacity, as well as prices of the inputs and outputs. The questionnaires were administered to catfish farmers using different construction designs, number of operational cycles, mode of selling and market price of catfish.

\section{Analytical techniques}

Analytical methods employed include descriptive statistics, profitability analysis, DEA and linear regression model. Descriptive statistics such as averages, percentages, tables were used to analyse information on socioeconomic variables. To determine profitability of catfish production, the gross margin was carried out. Gross margin is the difference between total revenue and total variable cost. The assumption is that the higher the gross margin, the higher the profit made by the farmers.

The mathematical notation for the analysis is presented below:

$$
\begin{aligned}
& \mathrm{GM}=\mathrm{TR}-\mathrm{TVC} \\
& \mathrm{TR}=\mathrm{PQ} \\
& \mathrm{TVC}=\mathrm{XM}
\end{aligned}
$$

where $\mathrm{GM}=$ Gross Margin, $\mathrm{TR}=$ Total Revenue, $\mathrm{P}=$ Price of catfish per $\mathrm{kg}, \mathrm{Q}=$ Output of construction designs producing catfish, $\mathrm{XM}=$ Market price of variable input.

The net revenue was also calculated using the formula below:

$$
\begin{aligned}
\text { Net revenue } & =\text { Total income }- \text { Total cost } \\
\text { Total cost } & =\text { Fixed cost }+ \text { Variable cost }
\end{aligned}
$$

\section{Data envelopment analysis (DEA)}

Data Envelopment Analysis (DEA) is an alternative nonparametric method for measuring efficiency that uses mathematical programming rather than regression. This efficiency measure corresponds to the coefficient of resource utilization defined by Charnes et al. [9]. Charnes et al. [9] introduced the method of Data Envelopment Analysis (DEA) to address the problem of efficiency measurement for decision-making units (DMUs) with multiple inputs and multiple outputs in the absence of market prices.
To analyse the technical efficiency of the four different construction designs for catfish farmers in the study area, Data Envelopment Analysis (DEA) will be used. The key construct of a DEA model is the envelopment surface and the efficient projection path to the envelopment surface [9]. The envelopment surface will differ depending on the scale assumptions that underline the model. The efficiency projection path to the envelopment/surface will differ depending on if the model is output-oriented or input-oriented. The choice of model depends upon optimization production process characterizing the firm. Input-oriented DEA determines how much the mix for a firm would have to change to achieve the output level that coincides with the best practice frontier. Output-oriented DEA is used to determine a firm's potential output given its inputs mix if operated as efficiently as firms along the best practice frontier. For this study input-oriented DEA will be used to determine how much input mix the farmers would have to change to achieve the output level that coincides with the best practice frontier. DEA is a relative measure of efficiency where the general problem is given as:

$$
\operatorname{Max} \mathrm{TE}=\frac{\sum_{r=1}^{s} \alpha_{r} y_{r o}}{\sum_{r=1}^{m} \beta_{i} X_{i o}}=\frac{q}{q^{*}}
$$

Subject to:

$$
\begin{aligned}
& \quad \frac{\sum_{r=1}^{s} \alpha_{r} y_{r j}}{\sum_{r=1}^{m} \beta_{i} X_{i j}} \leq 1, \quad j=1, \ldots, n \\
& { }_{r}, \cdot_{i}=0, r=1, \ldots, s ; \mathrm{l}=1, \ldots, m .
\end{aligned}
$$

Where, TE is technical efficiency, $x_{\mathrm{ij}}$ and $\mathrm{y}_{\mathrm{rj}}$, respectively, are quantities of the $i$ th input and $r$ th output of the $j$ th farms.

Inputs $=$ Stocking density, labour, feed.

Output $=$ Table size fish of catfish

Farms $=1 \ldots . . . \mathrm{n}$

$\cdot_{i}$ and $\cdot_{j}$ are input and output weights, respectively.

The variables of Data Envelopment model are further elucidated upon below

$Y_{i j}=$ output

$X_{i j}$ 's are:

Farm size: The output of a fish farm is partly dependent on the stocking density of the construction designs.

Labour: Family and hired labours play an important role in agricultural production especially in developing economies where capital is less significant.

Feed: This is the compounded feedstuff given to fish either imported or local feed. It is one of the major determinants of productivity in catfish production. It is measured in $15-\mathrm{kg}$ bag. 
Regression analysis: Farmers' specific characteristics were modelled as determinants of efficiency to understand how these characteristics influence the level of efficiency of the fish farmers.

$$
\begin{aligned}
& Y=f\left(X_{1}, X_{2}, X_{3}, X_{4}, X_{5}, \ldots, X 7, \varepsilon_{i}\right) \\
& Y=\text { Technical Efficiency (derived from DEA Model) } \\
& \text { where, } \\
& X_{1}=\text { Sex dummy variables (male }=1 \text {, otherwise }=0 \text { ) } \\
& X_{2}=\text { Age (years) } \\
& X_{3}=\text { Educational level (years) } X_{4}=\text { Marital Status } \\
& \text { (married }=1 \text { and } 0 \text { otherwise) } \\
& X_{5}=\text { Household size (number) } X_{6}=\text { Religion (Chris- } \\
& \text { tianity }=1 \text {, others }=0 \text { ) } \\
& X_{7}=\text { Primary occupation } \\
& \varepsilon_{i}=\text { error tem }
\end{aligned}
$$

\section{Results and discussion}

Profitability and budgetary analysis of different construction designs

Table 1 indicates the profitability of catfish production under different construction designs. As shown in
Table 1, the profitability of the different construction designs are 19, 713,750 (earthen pond), $10,160,050$ (plastic tank) and 24, 717, 180 (cage culture). The net revenue are $15,923,550, \ldots 3,739,550$, and $\# 2$, 067, 680 , respectively. And the undiscounted benefit/cost ratios (BCR) are 2.11, 1.32 and 1.06, respectively. This shows that the most profitable of the three construction designs is the earthen pond. For example, using the BCR estimate, it means that for every one Naira invested, the investor will get two Naira.

\section{Overall efficiency estimates of construction designs in terms of Variable Returns to Scale (VRS) and Constant Returns to Scale (CRS)}

Table 2 shows the frequency distribution of construction designs in terms of Variable Returns to Scale (VRS) and Constant Returns to Scale (CRS). Technical efficiency

\begin{tabular}{|c|c|c|c|c|c|c|c|c|c|c|c|c|}
\hline \multirow[t]{3}{*}{ TSCORES } & \multicolumn{4}{|c|}{ Earthen pond (EP) } & \multicolumn{4}{|c|}{ Cage culture (CC) } & \multicolumn{4}{|c|}{ Plastic tank (PT) } \\
\hline & \multicolumn{4}{|c|}{ VRS CRS } & \multicolumn{4}{|c|}{ VRS CRS } & \multicolumn{4}{|c|}{ VRS CRS } \\
\hline & $F$ & $\%$ & $F$ & $\%$ & $F$ & $\%$ & $F$ & $\%$ & $F$ & $\%$ & $F$ & $\%$ \\
\hline $0.6001-0.7000$ & 3 & 6.98 & 19 & 44.19 & 2 & 6.06 & 11 & 33.33 & 0 & 0 & 23 & 62.16 \\
\hline $0.7001-0.8000$ & 6 & 13.95 & 14 & 32.56 & 5 & 15.15 & 9 & 27.27 & 2 & 5.41 & 8 & 21.62 \\
\hline $0.8001-0.9000$ & 5 & 11.63 & 8 & 18.60 & 3 & 9.09 & 2 & 6.06 & 6 & 16.22 & 5 & 13.51 \\
\hline $0.9001-0.9999$ & 2 & 4.65 & 1 & 2.33 & 0 & 0 & 10 & 30.30 & 5 & 13.51 & 1 & 2.70 \\
\hline 1 & 27 & 62.79 & 1 & 2.33 & 22 & 66.67 & 1 & 3.03 & 24 & 64.86 & 0 & 0 \\
\hline Total & 43 & 100 & 43 & 100 & 33 & 100 & 33 & 100 & 37 & 100 & 37 & 100 \\
\hline Mean & 0.93 & & 0.73 & & 0.93 & & 0.79 & & 0.96 & & 0.69 & \\
\hline Median & 1 & & 0.71 & & 1 & & 0.74 & & 1 & & 0.65 & \\
\hline Mode & 1 & & 0.65 & & 1 & & 0.65 & & 1 & & 0.65 & \\
\hline Minimum Val & 0.66 & & 0.65 & & 0.69 & & 0.65 & & 0.79 & & 0.65 & \\
\hline Maximum Val & 1 & & 1 & & 1 & & 0.90 & & 1 & & 0.91 & \\
\hline SD & 0.12 & & 0.90 & & 0.12 & & 1 & & 0.68 & & 0.74 & \\
\hline
\end{tabular}
under the Variable Returns to Scale (VRS) under normal circumstance in cage culture shows that $66.67 \%$ of it is fully efficient and in plastic tank it is fully efficient at $64.86 \%$ and in earthen ponds it is fully efficient at $62.93 \%$. The average overall technical efficiency in earthen ponds is 0.93 , in cage culture is 0.93 and in plastic tank is 0.96 .

Table 1 Profitability and budgetary analysis of different construction designs

\begin{tabular}{llll}
\hline $\begin{array}{l}\text { Construction design } \\
\text { (CD) }\end{array}$ & Gross margin (TR-TVC) & Net revenue analysis (TR-TC) & Benefit/cost ratio (TR/TC) \\
\hline Earthen & $\mathrm{N} 30305000-\mathrm{N} 10591250=\mathrm{N} 19713750$ & $\mathrm{~N} 30305000-\mathrm{N} 14381450=\mathrm{N} 15923550$ & $30,305,000 / 14,381,450=2.11$ \\
Cage culture & $\mathrm{N} 36600000-\mathrm{N} 11882820=\mathrm{N} 24717180$ & $\mathrm{~N} 36600000-\mathrm{N} 34532320=\mathrm{N} 2067680$ & $36,600,000 / 34,532,320=1.06$ \\
Plastic tank & $\mathrm{N} 15440000-\mathrm{N} 5279950=\mathrm{N} 10160050$ & $\mathrm{~N} 15440000-\mathrm{N} 11700450=\mathrm{N} 3739550$ & $15,440,000 / 11,700,450=1.32$ \\
\hline
\end{tabular}

Source: Computed from survey data

Table 2 Overall efficiency of construction designs in terms of VRS and CRS 
Under the Constant Returns to Scale (CRS) under normal circumstance, the cage culture is fully efficient at $3.03 \%$. In the earthen pond, it is fully efficient at $2.33 \%$, while none of the ponds is fully efficient in plastic tank. The average overall technical efficiency in terms of CRS in earthen ponds is 0.73 ; in cage culture, it is 0.79 and in plastic tank, it is 0.69 . Substantial inefficiency occurred in the construction designs by catfish producers, and this implies that some of the catfish producers were not operating at an efficient scale and improvement in the overall efficiencies could be achieved if the farmers adjusted their scale of operations.

\section{Overall efficiency estimates of construction designs in terms of scale efficiency (SE)}

Table 3 shows the frequency distribution of construction designs in terms of scale efficiency (SE). Due to variation in CRS and VRS, scale efficiency (SE), under normal circumstance in earthen ponds is fully efficient at $2.33 \%$, in cage culture it is at $3.03 \%$, and none of the ponds in plastic tank is technically efficient. The construction design that is fully efficient is cage culture because it has the highest percentage in terms of scale efficiency (SE). The average overall technical efficiency in terms of SE in earthen ponds is 0.80 ; in cage culture, it is 0.86 and in plastic tank, it is 0.93 . Substantial inefficiency occurred in the construction designs by catfish producers, and this implies that some of the catfish producers were not operating at an efficient scale and improvement in the overall efficiencies could be achieved if the farmers adjusted their scale of operations.

\section{Determinants of CRS technical efficiency under earthen} pond, cage culture and plastic tank construction designs Table 4 shows regression estimate for earthen ponds, cage culture and plastic tank under CRS specification.
Under CRS, two variables had significant effects on technical efficiency of earthen ponds. These are sex which had a coefficient of -0.816278 and a $t$ value of -2.10 and significant at $5 \%$; this implies that an increase in the number of female catfish producers by $5 \%$ will likely lead to a decrease in technical by -.081628 and an increase in male catfish producers by 8. Men have the likelihood of increasing technical efficiency in catfish production. Age had a coefficient of 0.006071 and a t value of 1.82 and significant at $10 \%$, and this implies that an increase in age of catfish farmers has the likelihood of increasing technical efficiency. This could be because of the increase in experience as age increases.

For the cage culture under CRS specification, two variables had significant effects on the technical efficiency of the cage culture. These are level of education and primary occupation. While the coefficient of level of education is positive implying that the higher the educational level, the higher the likelihood of technical efficiency increasing, the coefficient of primary occupation is also positive negative.

However, for the plastic tank under CRS specification, two variables had significant effects on technical efficiency of this construction design. These are age which had a coefficient of 0.021552 and a $t$ value of 2.04 and significant at $5 \%$, implying that an increase in age of catfish producers using plastic tank has the likelihood of increasing technical efficiency by 0.012552 as depicted by the marginal effect. This shows that experience of the farmers increases with age. Religion had a coefficient of 0.2443532 and a $t$ value of 1.99 and significant at $10 \%$.

Table 3 Overall efficiency of construction designs in terms of scale efficiency (SE)

\begin{tabular}{|c|c|c|c|c|c|c|}
\hline \multirow[t]{2}{*}{ TESCORES } & \multicolumn{2}{|c|}{ Earthen pond (EP) } & \multicolumn{2}{|c|}{ Cage culture (CC) } & \multicolumn{2}{|c|}{ Plastic tank (PT) } \\
\hline & $F$ & $\%$ & $F$ & $\%$ & $F$ & $\%$ \\
\hline $0.6001-0.7000$ & 10 & 23.26 & 4 & 12.12 & 7 & 45.96 \\
\hline $0.7001-0.8000$ & 13 & 30.23 & 7 & 21.21 & 11 & 29.73 \\
\hline $0.8001-0.9000$ & 10 & 23.26 & 6 & 18.18 & 5 & 13.51 \\
\hline $0.9001-0.9999$ & 9 & 20.93 & 15 & 45.45 & 4 & 10.81 \\
\hline 1 & 1 & 2.33 & 1 & 3.03 & 0 & 0 \\
\hline Total & 43 & 100 & 33 & 100 & 37 & 100 \\
\hline Mean & 0.80 & & 0.86 & & 0.73 & \\
\hline Median & 0.79 & & 0.89 & & 0.71 & \\
\hline Mode & 0.65 & & 0.94 & & 0.75 & \\
\hline Minimum Val & 0.65 & & 0.65 & & 0.65 & \\
\hline Maximum Val & 1 & & 1 & & 0.91 & \\
\hline SD & 0.12 & & 0.86 & & 0.93 & \\
\hline
\end{tabular}

Source: Computed from survey data 
Table 4 Results of CRS regression analysis for earthen pond, cage culture and plastic tank

\begin{tabular}{|c|c|c|c|c|c|c|}
\hline Variable & Earthen pond (EP) & Cage culture (CC) & Plastic tank (PT) & Marginal effect (EP) & Marginal effect (CC) & Marginal effect (PT) \\
\hline Const & $\begin{array}{l}0.699035^{* * *} \\
(0.215109)\end{array}$ & $\begin{array}{l}0.944383^{* *} \\
(0.456234)\end{array}$ & $\begin{array}{l}0.600425^{* * *} \\
(0.230787)\end{array}$ & & & \\
\hline Sex & $\begin{array}{l}-0.081628^{* *} \\
(0.038828)\end{array}$ & $\begin{array}{l}0.0329918 \\
(0.051195)\end{array}$ & $\begin{array}{l}-0.851995 \\
(0.059994)\end{array}$ & -0.081628 & 0.329918 & -0.851995 \\
\hline Age & $\begin{array}{l}0.006071^{*} \\
(0.003328)\end{array}$ & $\begin{array}{l}0.004336 \\
(0.006365)\end{array}$ & $\begin{array}{l}0.012552^{* *} \\
(0.006150)\end{array}$ & 0.006071 & 0.004336 & 0.021552 \\
\hline Loedu & $\begin{array}{l}0.059853 \\
(0.051778)\end{array}$ & $\begin{array}{l}0.014690^{* *} \\
(0.007016)\end{array}$ & $\begin{array}{l}0.075929 \\
(0.137814)\end{array}$ & 0.059853 & 0.014690 & 0.075929 \\
\hline MS & $\begin{array}{l}0.002317 \\
(0.038502)\end{array}$ & $\begin{array}{l}-0.110483 \\
(0.079786)\end{array}$ & $\begin{array}{l}0.035553 \\
(0.095754)\end{array}$ & 0.002317 & -0.110483 & 0.355534 \\
\hline $\mathrm{HHS}$ & $\begin{array}{l}-0.006345 \\
(0.038224)\end{array}$ & $\begin{array}{l}0.012930 \\
(0.036218)\end{array}$ & $\begin{array}{l}-0.011898 \\
(0.008926)\end{array}$ & -0.006345 & 0.012930 & -0.011898 \\
\hline REL & $\begin{array}{l}0.037042 \\
(0.038224)\end{array}$ & $\begin{array}{l}0.841597 \\
(0.068971)\end{array}$ & $\begin{array}{l}0.244353^{*} \\
(0.123038)\end{array}$ & 0.037042 & 0.841587 & 0.244353 \\
\hline POCCUP & $\begin{array}{l}0.013553 \\
(0.050137)\end{array}$ & $\begin{array}{l}0.120017^{* *} \\
(0.055620)\end{array}$ & $\begin{array}{l}0.115385 \\
(0.082589)\end{array}$ & 0.013553 & 0.120017 & 0.115385 \\
\hline $\begin{array}{l}\text { Sigma } \\
\text {-2 Log-likelihood }\end{array}$ & $\begin{array}{l}0.103190 \\
34.540834\end{array}$ & $\begin{array}{l}0.127086 \\
9.422486\end{array}$ & $\begin{array}{l}0.113870 \\
0.898005\end{array}$ & & & \\
\hline
\end{tabular}

Source: Computed from survey data; ${ }^{* * *},{ }^{* *}$ and $*$ are coefficients significant at $1 \%, \% \%$ and $10 \%$, respectively. Figures in parenthesis are standard errors

\section{Conclusion and recommendations}

The study examined technical efficiency of catfish farmers using different construction designs in Lagos State, Nigeria. Results of data analysis revealed that generally, catfish production is very profitable irrespective of the type of designs used. However, the earthen pond design is the most profitable among all the designs in the study area. This is revealed by the estimates obtained for net revenue and the benefit/cost ratios. Again, in terms of factor influencing technical efficiency, age, sex, education, religion and primary occupation were very significant. Based on the findings, the following recommendations are made:

1. Effort should be geared towards building capacity of catfish farmers since education was found to be positively associated with increased technical efficiency.

2. Female farmers should be encouraged to take up catfish production as an income generating venture since women farmers were more technically efficient in the earthen pond and plastic tank construction designs. This can be done through improvement in girl-child education.

\section{Abbreviations}

AE: allocative efficiency; BCR: benefit/cost ratio; CBN: Central Bank of Nigeria; CC: cage culture; CD: construction design; CRS: constant returns to scale; DEA: data envelopment analysis; DMU: decision making unit; DMUs: decision making units; EE: economic efficiency; EP: Earthen pond; FAO: Food and Agriculture Organization; FDF: Federal Department of Fisheries; GDP: gross domestic product; GM: gross margin; LGAs: local government areas; LSADA: Lagos State Agricultural Development Authority; PT: plastic tank; SE: scale efficiency; SFA: stochastic frontier analysis; TC: total cost; TE: technical efficiency; TR: total revenue; TVC: total variable cost; VRS: variable returns to scale.

\section{Authors' contributions}

Both authors contributed to the study in terms of conceptualization, literature review, data analysis, result interpretations and editorials.

\section{Author details}

${ }^{1}$ Department of Agricultural Economics and Animal Production, University of Limpopo, Mankweng, South Africa. ${ }^{2}$ Department of Agricultural Economics, University of Ibadan, Ibadan, Nigeria.

\section{Acknowledgements}

Not applicable.

Competing interests

I also declare that the manuscript has no potential competing interests.

\section{Availability of data and materials}

Not applicable.

\section{Consent for publication}

Not applicable

\section{Ethics approval and consent to participate}

All necessary protocols were observed in the course of data collection and interaction with the respondents.

Funding

Not applicable.

\section{Publisher's Note}

Springer Nature remains neutral with regard to jurisdictional claims in published maps and institutional affiliations.

Received: 16 April 2018 Accepted: 3 January 2019

Published online: 15 January 2019 


\section{References}

1. Adeniyi JP. Fish consumption in Nigeria implications for fishery development policies M.Sc. thesis submitted to Department of Agriculture Economics and Farm Management, University of Ilorin. FAO. 2004. Fisheries country profiles. Rome, FAO. 2002. p. 124

2. Agbo AD. Bridging the fish demand, supply gap in Nigeria. Daily Trust, 14 May, 2015 p. 23

3. Ajao AO. Determinants of technical efficiency differentials among concrete and Earthen pond operators in Oyo State-Nigeria. Br J Arts Soc Sci. 2012;4(2):23-36

4. Banker R, Charnes D, Cooper WW. Some models for estimating technical and scale inefficiencies in data envelopment analysis. Manag Sci. 1984;30(9):1078-92.

5. Battese GE, Coelli TG. A model for technical inefficiency effect in stochastic frontier production for panel data. Empir Econ. 1995;20:325345.

6. Battese GE. Frontier production functions and technical efficiency: a survey of empirical applications in agricultural economics. Agric Econ. 1992;7:185-208.

7. Bravo-ureta BE, Pinheiro AE. Technical, economic, and allocative efficiency in peasant farming: evidence from the Dominican Republic. Dev Econ. 1997;35(1):48-67.

8. Central Bank of Nigeria (CBN). Agricultural credit guarantee scheme fund. Annual report and statement of accounts. CBN Publication, Abuja, Nigeria. 2004 p. 35.

9. Charnes A, Cooper WW, Rhodes E. Measuring efficiency of decision making units. Eur J Oper Res. 1978;2:429-44.

10. Coelli TG, Rao DSP, Battese G. An introduction to efficiency and productivity analysis. Boston: Kluwer; 1998. p. 349.

11. Coelli TG, Battese G. Identification of factors which influence the technical inefficiency of Indian farmers. Aust J Agric Econ. 1996;40(2):103-28.

12. Davies RWD, Cripps SJ, Nickson A, Porter G. Defining and estimating global marine fisheries bycatch. Mar Policy. 2009;2009(33):661-72.

13. Fare R, Grosskopf S, Lovell CAK. Production frontiers. Cambridge: Cambridge University Press; 1994. p. 66.

14. Farrell MJ. The measurement of productive efficiency. J R Stat Soc A (General). 1997;120:253-81.

15. FDF (2005) Report of presidential committee on fisheries and aquaculture development, vol 1: Consolidated Report. September, 2005. p. 63

16. Food and Agriculture Organisation (FAO). Economic analysis of supply and demand for food up to 2030 — special focus on fish and fishery products. FAO Fisheries and aquaculture Circular 1089. FIPM//C1089 (En), FAO, Rome, Italy, 2014, 20 pp.

17. Food and Agriculture Organisation (FAO) Dietary Assessment: A resource guide to method selection and application in low resource settings, Food and Agriculture Organisation of the United Nations, Rome, Italy. 2018. ISBN 978-92-5-130635-2, 172 pp.

18. Jarzebowshi S. Parametric and non-parametric efficiency measurement: the comparison of results. Quant Methods Econ. 2013;14(1):170-9.

19. Koopmans T. Analysis of production as an efficient combination of activities. In: Koopmans TC, editor. Activity analysis of production and allocation. New Haven: Yale University Press; 1951. p. 33-97.

20. Koutsoyiannis A. Modern microeconomics. 2nd ed. London: Macmillan Press; 1979. p. 462.

21. Krumbhakar SC, Lovell CAK. Stochastic frontier analysis. UK: Cambridge University Press; 2004. p. 20.

22. Lovell CAK. Production frontiers and productive efficiency. In: Fried HO, Lovelly CAK, Schmidt SS, editors. The measurement of productive efficiency: techniques and applications. Oxford: Oxford University Press; 1993. p. 3-67.

23. Mbanassor JA, Nwosu AC. Economic revival and sustenance in Nigeria. The analysis of livestock industry. Proceeding of silver anniversary conference of NASP/WASAP inaugural conference March 21-26, Nigeria 1998 Paper no. 223, p. 442.

24. Nkamleu GB. Productivity growth, technical progress and efficiency change in African agriculture. Afr Dev Rev. 2004;16(1):203-22.

25. Niang T, Jubrin S (2001) Quarterly newsletter of the Nigeria Agriculture Question and Answer Service 2001, 1(3).

26. Oluwatayo IB, Sekumade AB, Adesoji SA. Resource use efficiency of maize farmers in rural Nigeria: evidence from Ekiti State. World J Agric Sci. 2008;4(1):91-9.

27. Onoja GO. Fish and poverty. Agribus Today. 2005;1(8):5-7.

28. Osawe M. Technical know-how of Catfish Grow out for Table size in 4-6 months. Proceedings of seminar on modern fish farming by dynamo Catfish production, Lagos, 2007, p. 1-14.

29. Samson YA. Introduction to aquaculture and fisheries management in Nigeria. Abeokuta: Goal Education Publishing; 1997. p. 165.

30. Seiford LM. Data envelopment analysis: the evolution of the state of the art. J Prod Anal. 1996;3:99-137.

31. Ubesie AC, Ibeziakor NC. High burden of protein-energy malnutrition in Nigeria: beyond the health care setting. Ann Med Health Sci Res. 2012;2(1):66-9.
Ready to submit your research? Choose BMC and benefit from:

- fast, convenient online submission

- thorough peer review by experienced researchers in your field

- rapid publication on acceptance

- support for research data, including large and complex data types

- gold Open Access which fosters wider collaboration and increased citations

- maximum visibility for your research: over $100 \mathrm{M}$ website views per year

At BMC, research is always in progress.

Learn more biomedcentral.com/submissions 